\title{
Isolation, Purification, and Characterization of Five Active Diketopiperazine Derivatives from Endophytic Streptomyces SUK 25 with Antimicrobial and Cytotoxic Activities
}

\author{
Muhanna M. Alshaibani ${ }^{1}$, Noraziah MohamadZin ${ }^{1 *}$, Juriyati Jalil ${ }^{2}$, Nik Marzuki Sidik ${ }^{3}$, Siti Junaidah Ahmad ${ }^{1}$, \\ Nurkhalida Kamal ${ }^{4,5}$, and RuAngelie Edrada-Ebel ${ }^{4}$ \\ ${ }^{1}$ Programme of Biomedical Science, School of Diagnostic and Applied Health Sciences, Faculty of Health Sciences, Universiti Kebangsaan \\ Malaysia, Jalan Raja Muda Abdul Aziz, 50300 Kuala Lumpur, Malaysia \\ ${ }^{2}$ Drug and Herbal Research Centre, Faculty of Pharmacy, Universiti Kebangsaan Malaysia, Jalan Raja Muda Abdul Aziz, 50300 Kuala \\ Lumpur, Malaysia \\ ${ }^{3}$ Faculty of Ago-based Industry, Universiti Malaysia Kelantan, 17600 Jeli, Kelantan, Malaysia \\ ${ }^{4}$ Strathclyde Institute of Pharmacy and Biomedical Sciences, University of Strathclyde, Glasgow G4 ORE, Scotland \\ ${ }^{5}$ Department of Pharmaceutical Sciences, Faculty of Pharmacy, Cyberjaya University College of Medical Sciences, 63000 Cyberjaya, Selangor \\ Malaysia
}

Received: August 13, 2016

Revised: May 6, 2017

Accepted: May 21, 2017

First published online

May 24, 2017

*Corresponding author

Phone: +603-92897373;

Fax: +603-26929032;

E-mail: noraziah.zin@ukm.edu.my

pISSN 1017-7825, eISSN 1738-8872

Copyright(C) 2017 by

The Korean Society for Microbiology and Biotechnology
In our search for new sources of bioactive secondary metabolites from Streptomyces sp., the ethyl acetate extracts from endophytic Streptomyces SUK 25 afforded five active diketopiperazine (DKP) compounds. The aim of this study was to characterize the bioactive compounds isolated from endophytic Streptomyces SUK 25 and evaluate their bioactivity against multiple drug resistance (MDR) bacteria such as Enterococcus raffinosus, Staphylococcus aureus, Klebsiella pneumoniae, Acinetobacter baumanii, Pseudomonas aeruginosa, and Enterobacter spp., and their cytotoxic activities against the human hepatoma (HepaRG) cell line. The production of secondary metabolites by this strain was optimized through Thornton's medium. Isolation, purification, and identification of the bioactive compounds were carried out using high-performance liquid chromatography, high-resolution mass liquid chromatography-mass spectrometry, Fourier transform infrared spectroscopy, and nuclear magnetic resonance, and cryopreserved HepaRG cells were selected to test the cytotoxicity. The results showed that endophytic Streptomyces SUK 25 produces four active DKP compounds and an acetamide derivative, which were elucidated as cyclo-(L-Val-L-Pro), cyclo(L-Leu-L-Pro), cyclo-(L-Phe-L-Pro), cyclo-(L-Val-L-Phe), and N-(7-hydroxy-6-methyl-octyl)acetamide. These active compounds exhibited activity against methicillin-resistant S. aureus ATCC 43300 and Enterococcus raffinosus, with low toxicity against human hepatoma HepaRG cells. Endophytic Streptomyces SUK 25 has the ability to produce DKP derivatives biologically active against some MDR bacteria with relatively low toxicity against HepaRG cells line.

Keywords: Cytotoxicity, diketopiperazines, Enterococcus raffinosus, HepaRG, MRSA, Streptomyces SUK 25

\section{Introduction}

The development of antibiotic resistance among pathogenic bacteria has become a serious problem worldwide. The overuse of antibiotics in a number of situations is contributing to the increase in antibiotic resistance in microorganisms; therefore, the need for the detection and development of new and effective natural antibiotics is 
important. Streptomyces represent a large group of microorganisms that are ubiquitous in nature. Strain Universiti Kebangsaan 25 (SUK 25) is one strain that belongs to the genus Streptomyces sp., which was isolated from the root of Zingiber spectabile [1, 2]. SUK 25 exhibited potential inhibitory activity against some bacteria, especially against the methicillin-resistant Staphylococcus aureus (MRSA) strain during primary and secondary screenings. From SUK 25, several diketopiperazines (DKPs) were isolated, which were described from various natural resources [3]. DKPs create a large class of secondary metabolites synthesized mostly by human, plants, and microorganisms. DKPs are a class of cyclic dipeptides and characterized by a heterocyclic piperazine-2,5-dione synthesized from two amino acid units. Recently, the interest in these compounds has significantly increased because of their diverse and remarkable activity, and $90 \%$ of Gram-negative bacteria can produce DKPs [4]. Furthermore, DKPs have been isolated from Gram-positive bacteria [5], fungi [6], and higher marine organisms [7] as well.

The current study aimed to isolate and elucidate bioactive secondary metabolites from the endophyte Streptomyces SUK 25. The antimicrobial activity and cytotoxicity of some of the isolated compounds were evaluated. Cytotoxicity assay was carried out using the human hepatoma cell line named HepaRG, which is a unique cell line that differentiates canaliculae-like and hepatocyte-like cells retaining a drug metabolism capacity comparable to that of primary human hepatocytes and hepatoma carcinoma (HepG2) cells without inter-donor variability and functional instability with time in culture, which has been observed in primary cells [8-10]. In addition, these cells were obtained from a liver tumor cell of a female patient suffering from hepatocarcinoma and hepatitis $\mathrm{C}$ infection [11].

\section{Materials and Methods}

The fermentation, production, and extraction of secondary metabolites as well as chromatographic fractionation and purification of isolated compounds were carried out using reverse-phase open column chromatography and thin-layer chromatography (TLC) as described earlier [3].

\section{Biological Activity}

The antibacterial activity of the obtained compounds was tested against the multidrug resistance (MDR) pathogens Enterococcus raffinosus, Staphylococcus aureus, Klebsiella pneumoniae, Acinetobacter baumanii, Pseudomonas aeruginosa, and Enterobacter sp., collectively referred to by the acronym ESKAPE. All strains were obtained from the culture collection of the Novel Antibiotic Laboratory,
Faculty of Health Sciences, Universiti Kebangsaan Malaysia. Antimicrobial assays were carried out using the disc diffusion agar method. Antibacterial bioassays were conducted according to Dobretsov and Qian [12]. Compounds were dissolved in 10\% $\mathrm{MeOH}$ at a concentration of $1 \mathrm{mg} / \mathrm{ml}$. Aliquots of $20 \mu \mathrm{l}$ were soaked on filter paper discs (6 mm, No. 2668; Schleicher \& Schüll, Germany). A standard antibiotic disc of gentamicin (20 $\mu \mathrm{g} /$ disc) was used as the positive control and $10 \% \mathrm{MeOH}$ as the negative control for comparison. The paper discs were air dried at room temperature under sterilized conditions. Antibacterial effects were determined after $24 \mathrm{~h}$ of incubation at $37^{\circ} \mathrm{C}$ by measuring the diameter of the zone of inhibition.

\section{MTT Cell Viability Assay for Cytotoxicity Testing}

Cell viability was measured by the MTT colorimetric method [13]. This assay is based on the reduction of the soluble yellow 3-(4,5-dimethylthiazol-2-yl)-2,5-diphenyltetrazolium bromide (MTT) tetrazolium salt to a blue MTT formazan product by mitochondrial dehydrogenases. This assay was performed to determine the cytotoxicity of the two compounds namely, cyclo-(L-Val-L-Pro) and cyclo-(L-Phe-L-Pro). In this study, we followed the protocol from the manufacturer of cryopreserved HepaRG cells and media supplements (Millipore, USA). HepaRG cells were seeded in 96well plates at a density of $10^{4}$ cells per well and incubated in 5\% $\mathrm{CO}_{2}$ at $37^{\circ} \mathrm{C}$ for $24 \mathrm{~h}$. The cells were then treated with varying concentrations from 5 to $120 \mu \mathrm{g} / \mathrm{ml}$ and incubated in $5 \% \mathrm{CO}_{2}$ at $37^{\circ} \mathrm{C}$ for $24 \mathrm{~h}$. To determine the cell viability, $20 \mu \mathrm{lof} 5 \mathrm{mg}$ MTT/ $\mathrm{ml}$ in PBS was added to each well and incubated in $5 \% \mathrm{CO}_{2}$ for $4 \mathrm{~h}$ at $37^{\circ} \mathrm{C}$. The yellow MTT dye was reduced by succinic dehydrogenase in the mitochondria of viable cells to purple formazan crystals. Finally, the medium was carefully replaced with $200 \mu \mathrm{l}$ of DMSO and mixed thoroughly to dissolve the formazan crystal product. Absorbance measurements were conducted utilizing the microplate spectrophotometer NanoQuant infinite M200PRO at $\mathrm{A}_{570}$. A positive control composed of $10 \%$ DMSO was used as a known cytotoxic natural agent that gives $100 \%$ lethality under the same conditions. The samples also included a blank (medium alone). All experiments were carried out with hepatocytes from three independent cell preparations for each compounds' concentration.

Cell viability was calculated using the following formula: Cell viability $(\%)=\frac{\text { Mean OD of treated cells }}{\text { Mean OD of control cells }} \times 100$, where OD is the optical density. The half inhibitory concentration $\left(\mathrm{IC}_{50}\right)$ was defined as $50 \%$ reduction of absorbance compared with the control assay.

\section{Statistical Analysis}

The results were expressed as the mean \pm SD for all experiments. Triplicate experiments of three independent HepaRG isolations were run, and three wells were used for each set of conditions. $\mathrm{IC}_{50}$ values were calculated using GraphPad Prism 5.

\section{Spectroscopy and Structure Determination of Compounds}

Separation and final purification of the crude extract of each 


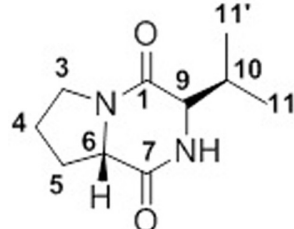

1<smiles>C[C@@H]1[C@@H]2CCN1C(=O)[C@H](Cc1ccccc1)NC2=O</smiles>

2<smiles>O=C1NC(C(=O)C(F)(F)F)C(=O)NC1Cc1ccccc1</smiles>

3<smiles>[Y7]C([Y2])C[C@H]1NC(=O)[C@@H]2SCCN2C1=O</smiles>

4

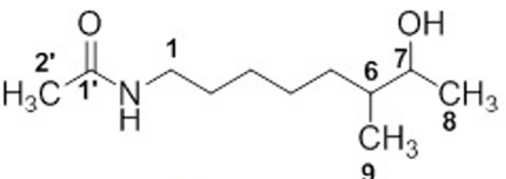

5

Fig. 1. Cyclo-(L-Val-L-Pro (1), cyclo-(L-Phe-L-Pro) (2), cyclo-(L-Leu-L-Pro) (3), cyclo-(L-Val-L-Phe) (4), and N-(7-hydroxy-6-methyloctyl)-acetamide (5).

fraction were performed using high-performance liquid chromatography (HPLC) on an Agilent 1200 HPLC system equipped with a C-18 column (size $4.6 \times 250 \mathrm{~mm}, 5 \mu \mathrm{m}$ ). In addition, the structure determination of compounds was determined using nuclear magnetic resonance (NMR) spectroscopy and FTNMR spectroscopy at $600 \mathrm{MHz}$ with Cryoprobe AVANCE III (Bruker, USA). For dereplication and exact mass measurements, HR-LCMS was measured on an Accela 600 HPLC pump with Accela autosampler coupled to a UV/Vis detector and an Orbitrap Exactive mass spectrometer (Thermo Fisher Scientific, Inc., USA). Analysis of samples was done using similar protocols described earlier by MacIntyre et al. [14]. Initially, the raw HR-LC/ESI/MS data were sliced into two data sets according to their ionization mode using the Mass Convert tool from ProteoWizard (http:// proteowizard.sourceforge.net/). The sliced data were imported to MZMine 2.10 (http://sourceforge.net/projects/mzmine/), a software developed for the differential analysis of mass spectrometry data. The data processing step was performed in the same manner as explained previously by MacIntyre et al. [14] and Abdelmohsen et al. [15], albeit with slightly modified parameters. In this analysis, the data set was crop filtered from 0.1 to $35 \mathrm{~min}$, and the retention time normalizer was not applied because only one batch of data was used. The processed data from MZMine was incorporated into the customized library through the built-in Excel MACRO for peak identification and dereplication. An algorithm was employed to use the molecular formula data set from Antibase 2013. The monoisotopic exact masses for each metabolite were then calculated to be used for the customized library. "Hits" and identified peaks were checked against the MS raw data in Xcalibur 2.2.

The FT-IR spectra were recorded on an FT-IR spectrophotometer (Perkin Elmer, USA) using the potassium bromide $(\mathrm{KBr})$ disc method. Optical rotation was measured on an Autopol VI automatic polarimeter (Rudolph Research Analysis, USA). The melting point was measured on a Stuart apparatus (Bibby Scientific, UK).

\section{Results}

The ethyl acetate extracts from endophytic Streptomyces SUK 25 produced four DKP compounds and an acetamide derivative (Fig. 1). They were identified as cyclo-(L-Val-LPro (1), cyclo-(L-Phe-L-Pro) (2), cyclo-(L-Leu-L-Pro) (3), cyclo(L-Val-L-Phe) (4), and N-(7-hydroxy-6-methyl-octyl)-acetamide (5), respectively, and were all isolated from fraction number II (FII; Table 1) after a series of chromatographic separation and purification using preparative HPLC. Structure elucidation was done by 1D and 2D NMR, as well as HR-LC/ESI/MS, as shown in Tables 2-5. The isolated DKPs 1, 2, 3, and 4 were obtained as colorless solids from FII with melting points of $216-221^{\circ} \mathrm{C}$. DKPs showed a UV absorbing band at $280 \mathrm{~nm}$ and turned violet upon spraying with anisaldehyde/sulfuric acid on a TLC silica plate. The NMR spectral data were comparable to those found in the literature [16, 17]. The NMR data (Tables 3 and 4) of the isolated DKP compounds gave characteristics ${ }^{13} \mathrm{C} \mathrm{NMR}$ shifts at approx. 165 and 170 ppm for the amide unit in the ring system. The ${ }^{1} \mathrm{H}$ NMR resonance at the $4 \mathrm{ppm}$ region is typical for a methine residue of an $\alpha$-proton of an amino acid unit, and the DKPs are synonymous to a cyclic dipeptide. The obtained NMR data for the proline-bearing

Table 1. Pure weight, diameter of inhibition zone, and MIC and $\mathrm{MBC}$ values of active fractions of fraction II against MRSA ATCC 43300.

\begin{tabular}{ccccc}
\hline Fraction No. & $\begin{array}{c}\text { Weight } \\
(\mathrm{mg})\end{array}$ & $\begin{array}{c}\mathrm{I} . \mathrm{Z} \\
(\mathrm{mm})\end{array}$ & $\begin{array}{c}\text { MIC } \\
(\mu \mathrm{g} / \mathrm{ml})\end{array}$ & $\begin{array}{c}\text { MBC } \\
(\mu \mathrm{g} / \mathrm{ml})\end{array}$ \\
\hline FII & 51 & 15 & 8 & 64 \\
\hline
\end{tabular}


Table 2. Name, formula, $m / z, \mathbf{R}_{T}$, and O.R $\mathbf{R}^{\circ}$ of five active diketopiperazine compounds isolated from fraction II.

\begin{tabular}{lcccc}
\hline \multicolumn{1}{c}{ Compound name } & Formula & $m / z$ & $\mathrm{R}_{T}$ & $\begin{array}{c}\mathrm{O} . \mathrm{R}^{\circ}-[\alpha] \mathrm{D} \\
(c=0.1, \mathrm{MeOH})\end{array}$ \\
\hline Cyclo-(L-Val-L-Pro) (1) & & 197.1285 & 3.45 & -324.6 \\
Cyclo-(L-Phe-L-Pro) (2) & $\mathrm{C}_{10} \mathrm{H}_{16} \mathrm{~N}_{2} \mathrm{O}_{2}$ & 5.33 & -138.2 \\
Cyclo-(L-Leu-L-Pro) (3) & $\mathrm{C}_{14} \mathrm{H}_{16} \mathrm{~N}_{2} \mathrm{O}_{2}$ & 245.1284 & 6.09 & -310.4 \\
Cyclo-(L-Val-L-Phe) (4) & $\mathrm{C}_{11} \mathrm{H}_{18} \mathrm{~N}_{2} \mathrm{O}_{2}$ & 211.1441 & 7.64 & -95.84 \\
N-(7-Hydroxy-6-methyl-octyl)-acetamide (5) & $\mathrm{C}_{14} \mathrm{H}_{18} \mathrm{~N}_{2} \mathrm{O}_{2}$ & 247.1440 & $-119.9^{\mathrm{a}}$ \\
\hline
\end{tabular}

${ }^{\mathrm{a}}\left(\mathrm{c} 0.25\right.$ in $\left.\mathrm{CHCl}_{3}\right)$.

Table 3. ${ }^{1} \mathrm{H}$ NMR and ${ }^{13} \mathrm{C}$ NMR spectral data of compounds $1-3$ in $\mathrm{MeOH}-d_{4}$.

\begin{tabular}{|c|c|c|c|c|c|c|c|c|c|}
\hline \multirow[b]{2}{*}{ Position } & \multicolumn{3}{|r|}{1} & \multicolumn{3}{|r|}{2} & \multicolumn{3}{|r|}{3} \\
\hline & $\begin{array}{l}\delta{ }^{13} \mathrm{C} \\
(\mathrm{ppm})\end{array}$ & $\begin{array}{c}\delta^{13} \mathrm{C} \\
(\mathrm{ppm})^{\mathrm{a}}\end{array}$ & $\begin{array}{c}\delta{ }^{1} \mathrm{H}(\mathrm{ppm}) \\
\text { multiplicity }(J \text { in } \mathrm{Hz})\end{array}$ & $\begin{array}{l}\delta^{13} \mathrm{C} \\
(\mathrm{ppm})\end{array}$ & $\begin{array}{c}\delta{ }^{13} \mathrm{C} \\
(\mathrm{ppm})^{\mathrm{a}}\end{array}$ & $\begin{array}{c}\delta{ }^{1} \mathrm{H}(\mathrm{ppm}) \\
\text { multiplicity }(J \text { in } \mathrm{Hz})\end{array}$ & $\begin{array}{l}\delta{ }^{13} \mathrm{C} \\
(\mathrm{ppm})\end{array}$ & $\begin{array}{c}\delta{ }^{13} \mathrm{C} \\
(\mathrm{ppm})^{\mathrm{a}}\end{array}$ & $\begin{array}{c}\delta^{1} \mathrm{H}(\mathrm{ppm}) \\
\text { multiplicity }(J \text { in } \mathrm{Hz})\end{array}$ \\
\hline 1 & $172.6(\mathrm{~s})$ & 169.7 & & 169.2 & 169.4 & & 170.3 & 170.2 & \\
\hline $3 \mathrm{~A}$ & $46.6(\mathrm{t})$ & 45.7 & $3.49(\mathrm{~m})$ & 44.6 & 45.4 & $3.13-3.58$ & 45.5 & 45.8 & $3.64-3.54$ \\
\hline 3B & & & $3.54(\mathrm{~m})$ & & & $3.13-3.58$ & & & $3.64-3.54$ \\
\hline 4 & $23.6(\mathrm{t})$ & 22.3 & $1.92(\mathrm{~m})$ & 21.6 & 22.5 & $1.24-1.84$ & 22.7 & 23.6 & $2.22-1.98$ \\
\hline $5 \mathrm{~A}$ & $29.9(\mathrm{t})$ & 28.5 & $2.31(\mathrm{ddd}, 11.9,6.9,1.3)$ & 27.9 & 28.3 & $2.31-2.37$ & 28.1 & 28.4 & 4.04 \\
\hline $5 B$ & & & $2.00(\mathrm{~m})$ & & & $2.31-2.37$ & & & 4.04 \\
\hline 6 & $61.2(\mathrm{~d})$ & 60.3 & $4.19(\mathrm{dd}, 6.9,1.3)$ & 58.7 & 59.0 & $4.46(\mathrm{dd} 10.6,2.7)$ & 59.0 & 59.2 & 4.15 \\
\hline 7 & $167.6(\mathrm{~s})$ & 164.6 & & 165.7 & 164.7 & & 166.1 & 166.2 & \\
\hline 9 & $59.7(d)$ & 58.7 & $4.02(\mathrm{~d}, 2.5)$ & 56.3 & 56.1 & $4.10(t, 7.6)$ & 53.4 & 53.6 & 2.37 \\
\hline 10 & $29.6(d)$ & 28.3 & $2.47(q, 6.9,6.9,2.5)$ & 36.3 & 36.7 & 3.19 & 38.6 & 38.9 & $2.22-1.98$ \\
\hline 11 & $16.4(\mathrm{q})$ & 16.0 & $0.93(\mathrm{~d}, 6.9)$ & & & & 24.7 & 25.0 & 1.55 \\
\hline $11^{\prime}$ & $18.6(\mathrm{q})$ & 19.2 & $1.08(\mathrm{~d}, 6.9)$ & & & & & & \\
\hline 12 & & & & & & & 23.3 & 23.1 & 1.03 \\
\hline $12^{\prime}$ & & & & & & & 21.2 & 21.5 & 0.96 \\
\hline $1^{\prime}$ & & & & 136.4 & 135.6 & $7.22-7.38$ & & & \\
\hline $2^{\prime} / 6^{\prime}$ & & & & 129.7 & 129.0 & $7.22-7.38$ & & & \\
\hline $3^{\prime} / 5^{\prime}$ & & & & 128.0 & 128.8 & $7.22-7.38$ & & & \\
\hline $4^{\prime}$ & & & & 127.0 & 127.3 & $7.22-7.38$ & & & \\
\hline
\end{tabular}

${ }^{a} \mathrm{NMR}$ data were compared with those acquired by Li et al. [16] in $\mathrm{CDCl}_{3}$.

DKPs were comparable to the L-DKPs described in the literature [17]. All optical rotation values for prolinecontaining DKPs (Table 2) gave a negative sign, indicating that the proline unit had the $S$ configuration [18]. The IR spectrum (KBr film) $V_{\max }$ of the DKPs exhibited absorption at 3,348, 2,479, 2,070, 1,394, 1,092, 1,121, and $972 \mathrm{~cm}^{-1}$, which indicated the presence of a C-N stretch and $\mathrm{H}-\mathrm{C}-\mathrm{H}-$ asymmetric stretch.

Compound 5, N-(7-hydroxy-6-methyl-octyl)-acetamide, was obtained as a colorless oil from FII as well, showing an UV absorbing band at $280 \mathrm{~nm}$. It gave a green coloration with anisaldehyde/sulfuric acid when sprayed on TLC silica plate. Data of the IR spectrum $\left(\mathrm{KBr}\right.$ film) yielded $V_{\max }$ absorbance at 3,356, 3,256, 2,966, 2,931, 1,683, 1,650, 1,530, and $1,447 \mathrm{~cm}^{-1}$. The optical rotation exhibited an $[\alpha] \mathrm{D}^{25}$ value of -119.9 (c 0.25 in $\mathrm{CHCl}_{3}$ ). ${ }^{1} \mathrm{H}$ and ${ }^{13} \mathrm{C}$ NMR spectroscopies were used for the characterization of compound 5 , which was elucidated as an aliphatic branched-amide. The NMR data (Table 5) suggested that this subfraction is similar to that of $\mathrm{N}$-(7-hydroxy-6-methyl-octyl)-acetamide isolated from terrestrial Streptomyces sp. GT 2005/079 [19]. The $\mathrm{m} / \mathrm{z}$ value of this compound was $202.1802[\mathrm{M}+\mathrm{H}]^{+}$eluting at $1.25 \mathrm{~min}$. The molecular formula $\mathrm{C}_{11} \mathrm{H}_{23} \mathrm{NO}_{2}$ was supported by the integration and multiplicity obtained from the ${ }^{1} \mathrm{H}$ and ${ }^{13} \mathrm{C}$ NMR data, respectively. $\mathrm{N}$-(7-Hydroxy-6-methyloctyl)-acetamide was earlier described to exhibit moderate 
Table 4. ${ }^{1} \mathrm{H}$ NMR and ${ }^{13} \mathrm{C}$ NMR data of compound 4 in $\mathrm{MeOD}^{\mathrm{b}}$.

\begin{tabular}{cccc}
\hline Position & $\begin{array}{c}\delta{ }^{1} \mathrm{H}(\mathrm{ppm}), \\
\text { multiplicity }(\mathrm{J} \text { in Hz) }\end{array}$ & $\begin{array}{c}\delta{ }^{13} \mathrm{C} \\
(\mathrm{ppm})\end{array}$ & $\begin{array}{c}\delta 13 \mathrm{C} \\
(\mathrm{ppm})^{\mathrm{a}}\end{array}$ \\
\hline $1-\mathrm{NH}$ & $8.0 \mathrm{brs}$ & & \\
2 & & $168.4(\mathrm{~s})$ & 167.41 \\
3 & $3.66(\mathrm{dd}, 4.4 .1 .6)$ & $59.2(\mathrm{~d})$ & 60.1 \\
$4-\mathrm{N} H$ & $8.0 \mathrm{brs}$ & & \\
5 & & $169.1(\mathrm{~s})$ & 67.3 \\
6 & $3.34(\mathrm{dt}, 4.9,1.4)$ & $55.0(\mathrm{~d})$ & 55.9 \\
$7 \mathrm{~A}$ & $3.26(\mathrm{dd}, 1.1,3.8)$ & $37.8(\mathrm{t})$ & 38.7 \\
$7 \mathrm{~B}$ & $3.01(\mathrm{dd}, 13.8 .4 .7)$ & & \\
8 & & $136.3(\mathrm{~s})$ & 137.2 \\
$9 / 13$ & $7.22(\mathrm{~d}, 6.9)$ & $130.3(\mathrm{~d})$ & 131.2 \\
$10 / 12$ & $7.28(\mathrm{t}, 6.8)$ & $127.9(\mathrm{~d})$ & 128.8 \\
11 & $7.23(\mathrm{t}, 7.2)$ & $126.4(\mathrm{~d})$ & 127.3 \\
14 & $1.6 \mathrm{~m}$ & $31.0(\mathrm{~d})$ & 31.9 \\
15 & $0.79,(\mathrm{t}, 6.9)$ & $18.2(\mathrm{q})$ & 19.1 \\
$15^{\prime}$ & $0.42,(\mathrm{t}, 6.9)$ & $16.2(\mathrm{q})$ & 17.1 \\
\hline
\end{tabular}

${ }^{a}$ NMR data were compared with those acquired by Stark and Hofmann [17] in DMSO-d . $_{6}$

${ }^{\mathrm{b}} \mathrm{MeOD}$, Deuterated methanol.

Table 5. ${ }^{1} \mathrm{H}$ NMR and ${ }^{13} \mathrm{C}$ NMR data of compound 5 in MeOD .

\begin{tabular}{ccc}
\hline Position & $\begin{array}{c}\delta{ }^{1} \mathrm{H}(\mathrm{ppm}) \\
\text { multiplicity }(J \text { in } \mathrm{Hz})\end{array}$ & $\begin{array}{c}\delta{ }^{13} \mathrm{C} \\
(\mathrm{ppm})\end{array}$ \\
\hline 1 & 3.66 & 39.6 \\
2 & $1.25-1.38$ & 32.3 \\
3 & $1.25-1.38$ & 26.7 \\
4 & $1.25-1.38$ & 27.1 \\
5 & $1.25-1.38$ & 29.5 \\
6 & & 39.9 \\
7 & 3.22 & 71.6 \\
8 & 1.18 & 19.4 \\
9 & 1.18 & 14.5 \\
$1^{\prime}$ & & 170.1 \\
$2^{\prime}$ & 1.97 & 23.3 \\
\hline
\end{tabular}

${ }^{\mathrm{a}} \mathrm{MeOD}$, Deuterated methanol.

activity against Mucor miehei [19]. However, in this current study, compound $\mathbf{5}$ displayed activity against Enterococcus raffinosus.

\section{Biological Activity}

Fraction FII exhibited activity against MRSA and Enterococcus raffinosus. The isolated pure compounds from
Table 6. Antimicrobial activity of the subfraction FII against ESKAPE pathogens by the disk diffusion method.

\begin{tabular}{lcccccc}
\hline $\begin{array}{c}\text { Name of bacteria } \\
\text { (ATCC) }\end{array}$ & $\mathbf{1}$ & $\mathbf{2}$ & $\mathbf{3}$ & $\mathbf{4}$ & $\mathbf{5}$ & Gentamicin \\
\hline ER (49464) & n.a. & n.a. & 13 & 14 & 13 & 20 \\
MRSA (43300) & 15 & n.a. & n.a. & n.a. & n.a. & 22 \\
KP & n.a. & n.a. & n.a. & n.a. & n.a. & 18 \\
AB & n.a. & n.a. & n.a. & n.a. & n.a. & 17 \\
PA (87853) & n.a. & n.a. & n.a. & n.a. & n.a. & 17 \\
EA (51697) & n.a. & n.a. & n.a. & n.a. & n.a. & 20
\end{tabular}

The determined inhibition zone was in milliliter unit.

ER, Enterococcus raffinosus; SA, Staphylococcus aureus; KP, Klebsiella pneumoniae; AB, Acinetobacter, baumanii; PA, Pseudomonas aeruginosa; and EA, Enterobacter aerogenes; and n.a., no activity.

Table 7. Data analysis from GraphPad Prism 5 to determine the $\mathrm{IC}_{50}$ of compounds $\mathbf{1}$ and $\mathbf{2}$ against the HepaRG cell line.

\begin{tabular}{lcc}
\hline $\begin{array}{c}\text { Log (inhibitor) vs. } \\
\text { normalized response - } \\
\text { Variable slope }\end{array}$ & $\mathbf{1}$ & $\mathbf{2}$ \\
\hline Log IC $\mathrm{C}_{50}$ & 2.042 & 2.014 \\
Hill slope & 1.242 & 1.137 \\
$\mathrm{IC}_{50}$ & 110.1 & 103.2 \\
Log IC & 0.02299 & 0.01765 \\
Hill slope & 0.1191 & 0.08189 \\
Confidence intervals & $95 \%$ & $95 \%$ \\
Log IC & 1.983 to 2.101 & 1.968 to 2.059 \\
Hill slope & 0.9354 to 1.548 & 0.9261 to 1.347 \\
IC $_{50}$ & 96.09 to 126.2 & 92.96 to 114.6 \\
Degrees of freedom & 5 & 5 \\
$\mathrm{R}^{2}$ & 0.9843 & 0.9913 \\
Absolute sum of squares & 34.8 & 19.82 \\
Sy.x & 2.638 & 1.991 \\
\hline
\end{tabular}

FII were tested against ESKAPE pathogens. Compound 1 showed bioactivity only against MRSA 43300 with a zone of inhibition at $15 \mathrm{~mm}$. Compounds 3,4 , and 5 were active only against Enterococcus raffinosus with a zone of inhibition at 13,14 , and $13 \mathrm{~mm}$, respectively. The pure compounds were examined against the different test microorganisms, as shown in Table 6.

\section{Cytotoxic Effects of C1 and C2 on HepaRG}

Tested compounds $\mathbf{1}$ and $\mathbf{2}$ showed no toxicity towards HepaRG cells, with $\mathrm{IC}_{50}$ values of $110.1 \pm 1.2$ and $103.2 \pm$ $1.24 \mu \mathrm{g} / \mathrm{ml}$ for $\mathbf{1}$ and $\mathbf{2}$, respectively, as shown in Table 7 and Fig. 2. 

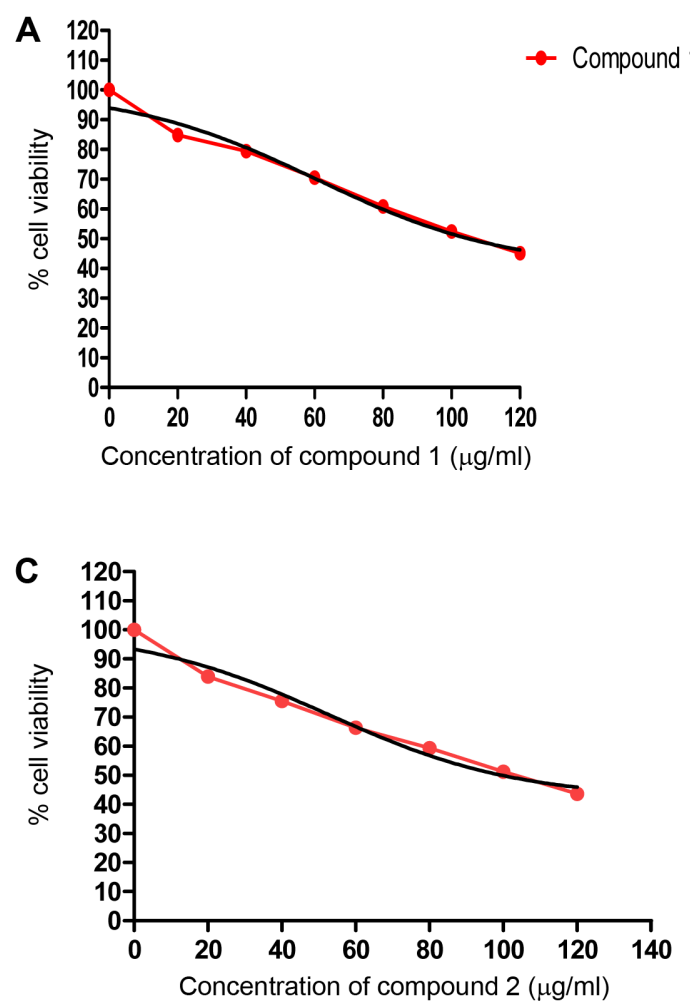

B

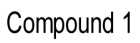

(1)

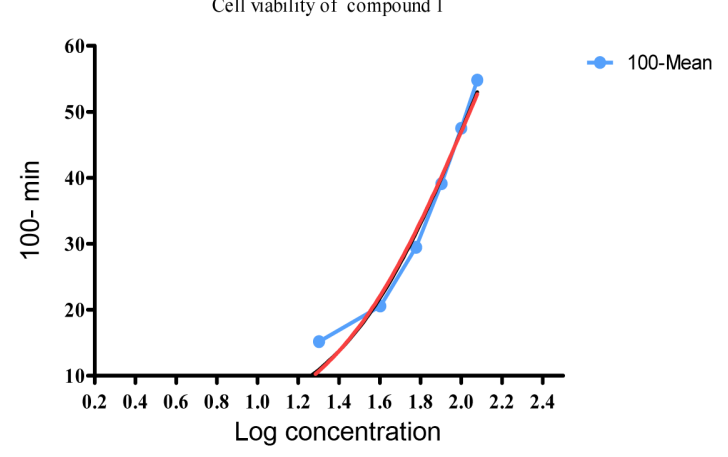

D

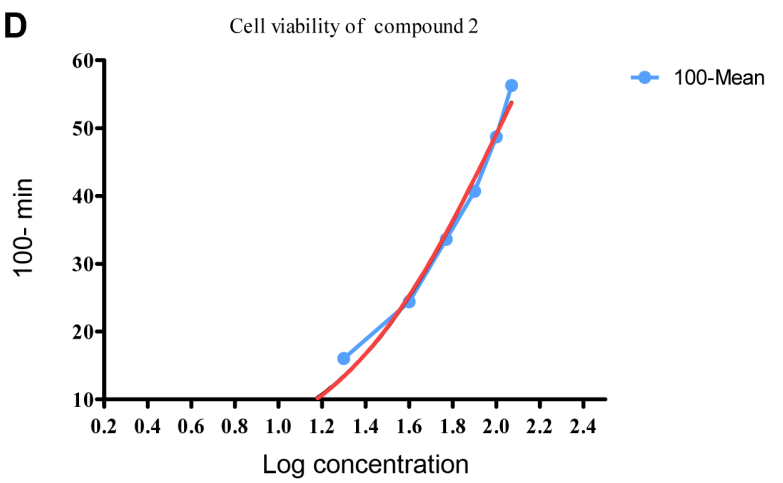

Fig. 2. Cytotoxic effects of compounds 1 and 2 on a cancer cell line (HepaRG).

Data are represent by the mean $\pm \mathrm{SD}$ of three independent experiments with each experiment conducted in triplicate. (A) and (C) present $\mathrm{IC}_{50}$ values of compounds 1 and 2; $110.1 \pm 1.2$ and $103.2 \pm 1.2$ respectively. (B) and (D) $\mathrm{IC}_{50}$ values of compounds 1 and 2 using GraphPad Prism in Log concentration Log (inhibitor) vs. normalized response - Variable slope.

\section{Discussion}

The antimicrobial bioactivity and cytotoxicity of the isolated compounds were evaluated using several types of bacteria and HepaRG cells, respectively. The ethyl acetate extract of Streptomyces SUK 25 produced four active DKP compounds and a N-(7-hydroxy-6-methyl-octyl)-acetamide. The DKPs were identified as cyclo-(L-Val-L-Pro (1), cyclo-(LPhe-L-Pro) (2), cyclo-(L-Leu-L-Pro) (3), and cyclo-(L-Val-L-Phe) (4). All pure compounds were isolated from fraction FII after a series of chromatographic separation and purification by HPLC. Structure elucidation was accomplished by HR-LC ESI MS and NMR. The findings from this study are simillar to an earlier work [20] on the isolation of four cyclic DKP antibiotics, identified as streptocidins A-D, from the mycelial extract of Streptomyces sp. Tü 6071. Moreover, cyclo-(valyl-prolyl) has been isolated from the marine actinomycete B 1758 [21], as well as cyclo-(L-Leu-L-Pro) from Streptomyces sp. KH-614, which is taxonomically related to Streptomyces lydicus. Cyclo-(L-Leu-L-Pro) demonstrated antibacterial activity against VRE strains such as E. faecalis
(K-99-34), E. faecalis (K-00-184), and E. faecalis (K-00-221) with MIC values of $12.5 \mu \mathrm{g} / \mathrm{ml}$. Moreover, cyclo-(L-Leu-LPro) was also described to be effective against three leukemic cell lines at concentrations below $100 \mu \mathrm{g} / \mathrm{ml}$ [22]. Cyclo-(L-Gly-L-Pro) and cyclo-(L-Phe-4-OH-L-Pro) were isolated from cultures of the marine bacterium Pseudoalteromonas luteoviolacea [23]. A combination of cyclo-(L-Leu-L-Pro) and cyclo-(L-Phe-L-Pro) exhibited increased bioactivity against Escherichia coli, Staphylococcus aureus, Micrococcus luteus, Candida albicans, and Cryptococcus neoformans with MIC values of $0.25-0.5 \mu \mathrm{g} / \mathrm{ml}$ [24]. Furthermore, seven DKPs known as cyclo-(L-Leu-L-Pro), cyclo-(L-Phe-L-Pro), cyclo-(Gly-L-Pro), cyclo-(L-Pro-L-Pro), cyclo-(L-Pro-L-Val), cyclo-(L-Leu-L-trans4-OH-Pro), and cyclo-(L-Phe-L-trans-4-OH-Pro) were isolated from a fermentation broth of Aspergillus fumigatus. These fungal DKPs exhibited weak antibacterial activity, inhibiting the growth of Staphylococcus aureus and Micrococcus luteus at the concentration of $2.9 \mathrm{mmol} / 1$ [25]. In addition, cyclo(L-Leu-L-Pro), also known as gancidin W, from two Streptomyces species inhibited the growth of VRE-resistant Enterococcus faecalis strains with MIC values of $12.5 \mu \mathrm{g} / \mathrm{ml}$ 
[26]. The marine sponge Axinella sp. also yielded six DKPs identified as cyclo-(threonyl-prolyl), cyclo-(seryl-prolyl), cyclo(alanyl-prolyl), cyclo-(leucyl-prolyl), cyclo-(valyl-prolyl), and cyclo-(glycyl-prolyl) [27]. Along with the cyclic tetrapeptide staphylopeptide A, five DKPs, cyclo-(L-Val-L-Pro), cyclo-(LTyr-L-Pro), cyclo-(L-Ala-L-Pro), and (L-Phe-L-Trp) were isolated from the culture broth of the marine bacterium Staphylococcus sp. no. P-100826-4-6 [28].

HepaRG cells were obtained from a liver tumor of a female patient suffering from hepatocarcinoma and hepatitis $\mathrm{C}$ infection [11]. The HepaRG cell line has been described as a tool in the prediction of hepatotoxicity in preclinical drug development $[11,29]$. The ability of these cells to express cytochrome P450 as well as nuclear receptors, the major hepatic membrane transporters, phase II enzymes, and antioxidant enzymes, particularly in their differentiated state, makes them a valuable in vitro model to perform drug metabolism and toxicity studies [9]. In the present work, compounds 1 and 2 showed no toxicity towards HepaRG cells, with $\mathrm{IC}_{50}$ values of $110.1 \pm 1.2 \mu \mathrm{g} / \mathrm{ml}$, and $103.2 \pm 1.24 \mu \mathrm{g} / \mathrm{ml}$, respectively, as shown in Table 7 and Fig. 2. The isolated compounds were categorized as non-toxic as recommended by the National Cancer Institute. $\mathrm{IC}_{50}$ values of crude extracts over $30 \mu \mathrm{g} / \mathrm{ml}$ were defined as negative cytotoxicity. The results from this study is comparable to an earlier work where a cyclodipeptide mixture obtained from Pseudomonas aeruginosa strain PAO1 gave $\mathrm{IC}_{50}$ values of 530 and $660 \mu \mathrm{g} / \mathrm{ml}$, against HeLa and Caco-2 cells, respectively [30].

The most important biological activities of DKPs, such as tryprostatins A and B, were demonstrated to treat tsFT210 cells at a $\mathrm{IC}_{50}$ concentration of $6.25,50$, and $12.5 \mu \mathrm{g} / \mathrm{ml}$, respectively. The DKPs arrested tsFT210 cells in the G2/M phase [31,32]. DKPs have displayed the ability to act as a plasminogen activator inhibitor-1 (PAI-1) [33, 34]. The mechanism of action of DKPs may lead to cause alteration of cardiovascular and blood-clotting functions [35]. The effects of acetylapoaranotin, acetylaranotin, and deoxyapoaranotin DKPs on cell proliferation were tested in vitro using five cancer cell lines (HCT116, AGS, A549, MCF-7, and HepG2) and showed potent inhibition of cell proliferation in four cancer cell lines with the exception of HepG2 cells [36]. A mixture of DKPs that consisted of cyclo-(L-Pro-L-Tyr), cyclo(L-Pro-L-Val), and cyclo-(L-Pro-L-Phe) isolated from the P. aeruginosa PAO1 strain was applied to human cells grown in serum containing CM medium. The results obtained showed that these DKPs caused a decrease in the viability of HeLa and Caco-2 cell cultures, exhibiting 75\% dead cells following treatment with the DKP mix at $100 \mathrm{mg} / \mathrm{ml}$. The
$\mathrm{IC}_{50}$ for that mix was 0.53 and $0.66 \mathrm{mg} / \mathrm{ml}$ for HeLa and Caco-2 cells, respectively. In addition, DKPs have the capability to inhibit the activity of regulatory LuxR-type proteins that are involved in $\mathrm{N}$-acylhomoserine lactone dependent quorum sensing signaling [30].

In conclusion, this study demonstrates that endophytic Streptomyces SUK 25 has the ability to produce various DKP derivatives with potential bioactivity against some pathogenic bacteria such as MRSA and Enterococcus raffinosus, with low toxicity against HepaRG cells. This finding presents a good potential natural source of new drugs for the treatment of some infectious diseases.

\section{Acknowledgments}

This research was supported by the Ministry of Higher Education (MOHE) under research grant code FRGS/1/ 2011/ST/UKM/02/1. The Authors would like to thank the Centre for Research \& Instrumentation (CRIM), Faculty of Dentistry (UKM). We also thank Prof. Jean Frederic Faizal Weber Abdullah, Dr. Salwa Rawih, and Atta-ur-Rahman Institute (UiTM) for their analytical assistance.

\section{References}

1. Zin N, Loi C, Sarmin N, Rosli A. 2010. Cultivationdependent characterization of endophytic actinomycetes. Res. J. Microbiol. 5: 717-724.

2. Junaidah AS, Suhaini S, Sidek HM, Basri DF, Zin NM. 2015. Anti-methicillin resistant Staphylococcus aureus activity and optimal culture condition of Streptomyces sp. SUK 25. Jundishapur J. Microbiol. 8: 1-7.

3. Alshaibani MM, Jalil J, Sidik NM, Edrada-Ebel R, Zin NM. 2016. Isolation and characterization of cyclo-(tryptophanylprolyl) and chloramphenicol from Streptomyces sp. SUK 25 with antimethicillin-resistant Staphylococcus aureus activity. Drug Des. Devel. Ther. 10: 1817-1827.

4. Fenical W. 1993. Chemical studies of marine bacteria: developing a new resource. Chem. Rev. 93: 1673-1683.

5. Stierle A, Cardellina Ii J, Singleton F. 1988. A marine Micrococcus produces metabolites ascribed to the sponge Tedania ignis. Experientia 44: 1021-1021.

6. Bugni TS, Ireland CM. 2004. Marine-derived fungi: a chemically and biologically diverse group of microorganisms. Nat. Prod. Rep. 21: 143-163.

7. Huang R, Zhou X, Xu T, Yang X, Liu Y. 2010. Diketopiperazines from marine organisms. Chem. Biodivers. 7: 2809-2829.

8. Gerets H, Tilmant K, Gerin B, Chanteux H, Depelchin B, Dhalluin $S$, et al. 2012. Characterization of primary human hepatocytes, HepG2 cells, and HepaRG cells at the mRNA level and CYP activity in response to inducers and their 
predictivity for the detection of human hepatotoxins. Cell Biol. Toxicol. 28: 69-87.

9. Guillouzo A, Corlu A, Aninat C, Glaise D, Morel F, Guguen-Guillouzo C. 2007. The human hepatoma HepaRG cells: a highly differentiated model for studies of liver metabolism and toxicity of xenobiotics. Chem. Biol. Interact. 168: 66-73.

10. Aninat C, Piton A, Glaise D, Le Charpentier T, Langouët $S$, Morel F, et al. 2006. Expression of cytochromes P450, conjugating enzymes and nuclear receptors in human hepatoma HepaRG cells. Drug Metab. Dispos. 34: 75-83.

11. Gripon P, Rumin S, Urban S, Le Seyec J, Glaise D, Cannie I, et al. 2002. Infection of a human hepatoma cell line by hepatitis B virus. Proc. Natl. Acad. Sci. USA 99: 15655-15660.

12. Dobretsov SV, Qian P-Y. 2002. Effect of bacteria associated with the green alga Ulva reticulata on marine micro- and macrofouling. Biofouling 18: 217-228.

13. Mosmann T. 1983. Rapid colorimetric assay for cellular growth and survival: application to proliferation and cytotoxicity assays. J. Immunol. Methods 65: 55-63.

14. MacIntyre L, Zhang T, Viegelmann C, Martinez IJ, Cheng C, Dowdells C, et al. 2014. Metabolomic tools for secondary metabolite discovery from marine microbial symbionts. Mar. Drugs 12: 3416-3448.

15. Abdelmohsen UR, Cheng C, Viegelmann C, Zhang $T$, Grkovic T, Ahmed S, et al. 2014. Dereplication strategies for targeted isolation of new antitrypanosomal actinosporins A and B from a marine sponge associated-Actinokineospora sp. EG49. Mar. Drugs 12: 1220-1244.

16. Li X, Dobretsov S, Xu Y, Xiao X, Hung OS, Qian PY. 2006. Antifouling diketopiperazines produced by a deep-sea bacterium, Streptomyces fungicidicus. Biofouling 22: 201-208.

17. Stark T, Hofmann T. 2005. Structures, sensory activity, and dose/response functions of 2,5-diketopiperazines in roasted cocoa nibs (Theobroma cacao). J. Agric. Food Chem. 53: 7222-7231.

18. Adamczeski M, Reed AR, Crews P. 1995. New and known diketopiperazines from the Caribbean sponge, Calyx cf. podatypa. J. Nat. Prod. 58: 201-208.

19. Rahman H. 2008. Unusual sesquiterpenes: gorgonenes and further bioactive secondary metabolites derived from marine and terrestrial bacteria. PhD Thesis. Göttingen University, Germany.

20. Gebhardt K, Pukall R, Fiedler H-P. 2001. Streptocidins AD, novel cyclic decapeptide antibiotics produced by Streptomyces sp. Tu 6071. I. Taxonomy, fermentation, isolation and biological activities. J. Antibiot. (Tokyo) 54: 428-433.

21. Šmelcerović AA, Schiebel M, Đorđević SM. 2002. The isolation of (6S, 9S)-cyclo (prolylvalyl) from marine actinomycete, by use of high speed contercurrent chromatography. J. Serbian Chem. Soc. 67: 27-30.

22. Rhee K-H. 2002. Isolation and characterization of Streptomyces sp. KH-614 producing anti-VRE (vancomycin-resistant enterococci) antibiotics. J. Gen. Appl. Microbiol. 48: 321-327.
23. Jiang Z, Boyd KG, Mearns-Spragg A, Adams DR, Wright PC, Burgess JG. 2000. Two diketopiperazines and one halogenated phenol from cultures of the marine bacterium, Pseudoalteromonas luteoviolacea. Nat. Prod. Lett. 14: 435-440.

24. Rhee K-H. 2004. Cyclic dipeptides exhibit synergistic, broad spectrum antimicrobial effects and have anti-mutagenic properties. Int. J. Antimicrob. Agents 24: 423-427.

25. Furtado NA, Pupo MT, Carvalho I, Campo VL, Duarte MCT, Bastos JK. 2005. Diketopiperazines produced by an Aspergillus fumigatus Brazilian strain. J. Braz. Chem. Soc. 16: 1448-1453.

26. de Carvalho MP, Abraham W-R. 2012. Antimicrobial and biofilm inhibiting diketopiperazines. Curr. Med. Chem. 19: 3564-3577.

27. Huang R, Yan T, Peng Y, Zhou X, Yang X, Liu Y. 2014. Diketopiperazines from the marine sponge Axinella sp. Chem. Nat. Compd. 50: 191-193.

28. Khedr AI, Mohamed GA, Orabi MA, Ibrahim SR, Yamada K. 2015. Staphylopeptide A, a new cyclic tetrapeptide from culture broth of Staphylococcus sp. Phytochem. Lett. 13: 11-14.

29. Szabo M, Veres Z, Baranyai Z, Jakab F, Jemnitz K. 2013. Comparison of human hepatoma HepaRG cells with human and rat hepatocytes in uptake transport assays in order to predict a risk of drug induced hepatotoxicity. PLoS One 8: e59432.

30. Vázquez-Rivera D, González O, Guzmán-Rodríguez J, DíazPérez AL, Ochoa-Zarzosa A, López-Bucio J, et al. 2015. Cytotoxicity of cyclodipeptides from Pseudomonas aeruginosa PAO1 leads to apoptosis in human cancer cell lines. Biomed. Res. Int. 2015: 197608.

31. Cui CB, Usukata M, Kakeya H, Onose R, Okada G, Takahashi I, et al. 1996. Acetophthalidin, a novel inhibitor of mammalian cell cycle, produced by a fungus isolated from a sea sediment. J. Antibiot. (Tokyo) 49: 216-219.

32. Kondoh M, Usui T, Mayumi T, Osada H. 1998. Effects of tryprostatin derivatives on microtubule assembly in vitro and in situ. J. Antibiot. (Tokyo) 51: 801-804.

33. Folkes A, Brown SD, Canne LE, Chan J, Engelhardt E, Epshteyn S, et al. 2002. Design, synthesis and in vitro evaluation of potent, novel, small molecule inhibitors of plasminogen activator inhibitor-1. Bioorg. Med. Chem. Lett. 12: 1063-1066.

34. Martins MB, Carvalho I. 2007. Diketopiperazines: biological activity and synthesis. Tetrahedron 63: 9923-9932.

35. McCleland K, Milne P, Lucieto F, Frost C, Brauns S, Venter M, et al. 2004. An investigation into the biological activity of the selected histidine-containing diketopiperazines cyclo (HisPhe) and cyclo (His-Tyr). J. Pharm. Pharmacol. 56: 1143-1153.

36. Choi E, Park JS, Kim YJ, Jung JH, Lee J, Kwon H, et al. 2011. Apoptosis-inducing effect of diketopiperazine disulfides produced by Aspergillus sp. KMD 901 isolated from marine sediment on HCT116 colon cancer cell lines. J. Appl. Microbiol. 110: 304-313. 